\title{
Mission in the Asian Multi-religious Context
}

\author{
A missão no contexto multirreligioso asiático
}

\author{
Joy Thomas*
}

St. Joseph's College, Jakhama, Nagaland, India

\begin{abstract}
The present moment is a time of great promise because of globalisation, technological advancement, growth in communication facilities and internet. People have come closer and become more interdependent. Yet, at the same time, increased violence, a growing forgetfulness of God, and consequent feelings of fear and insecurity have become a reality in the world over, particularly in Asia. Furthermore, such phenomena as religious fanaticism and terrorism threaten our future hopes. In this situation, we have to rediscover the meaning of the Christian mission in the emerging context. As the Church evangelises in a real world that is constantly changing, the emphasis in the activities of the church also changes with time. A new understanding of evangelization in the multiple context and new tools which should be used is the need of the time to make the Gospel relevant today.
\end{abstract}

Keywords: Mission. Religious diversity. Change. Cultural context.

*JT: Doctor, e-mail: joythomassvd@gmail.com 


\section{Resumo}

O momento atual é um tempo de grande promessa por causa da globalização, do avanço tecnológico, do crescimento dos meios de comunicação e internet. As pessoas se aproximaram mais e assim tornaram-se mais interdependentes. No entanto, ao mesmo tempo, aumento da violência, um crescente esquecimento de Deus, e consequentes sentimentos de medo e insegurança se tornaram uma realidade no mundo, particularmente na Ásia. Além disso, fenômenos como o fanatismo religioso e terrorismo ameaçam nossas futuras esperanças. Nessa situação, nós temos que redescobrir o sentido da missão cristã no contexto emergente. Como a lgreja evangeliza em um mundo real que está em constante mudança, a ênfase nas atividades da igreja também passa pela mudança com o tempo. Uma nova compreensão da evangelização no contexto múltiplo e que tipo de novas ferramentas devem ser usadas são as necessidades atuais para fazer o Evangelho relevante hoje.

Palavras-chave: Missão. Diversidade religiosa. Mudança. Contexto cultural.

\section{Introduction}

The present moment is a time of great promise because of globalisation, technological advancement, growth in communication facilities and internet. People have come closer and become more interdependent. Yet, at the same time, increased violence, a growing forgetfulness of God, and consequent feelings of fear and insecurity have become a reality in the world over, particularly in Asia. Furthermore, such phenomena as religious fanaticism and terrorism threaten our future hopes. In this situation, we have to rediscover the meaning of the Christian mission in the emerging context. As the Church evangelises in a real world that is constantly changing, the emphasis in the activities of the church also changes with time. A new understanding of evangelisation is called for in order to make the Gospel 'Good News' even today ${ }^{1}$.

1 Abbreviations used in this paper: Lumen Gentium (LG), Nostra Aetate (NA), Evangelii Nuntiandi (EN), Redemptoris Missio (RM), Novo Millennio Ineunte (NMI), Consejo episcopal latinoamericano (CELAM), Ad Gentes (AG), Ecclesia in Asia (EA), Redemptor Hominis (RH), Evangelii Gaudium (EG), Dialogue and Proclamation (DP), Indian Theological Association (ITA). 
In the multi-religious context of Asia, Evangelisation has a mutually complementary double process: Communion with Christ, in which the Church and people of different faiths and ideologies share their experience of their ultimate values, and an exchange of brotherly and sisterly praxis of concerns and care in a tangible form, as they strive together and cooperate with each other for a common end, i.e. fuller and authentic human life. So we need to respect followers of other religions as co-pilgrims. Hence, in the Asian context, "Christian mission is better termed missio inter gentes (mission among the people) than missio ad gentes" (mission to the people) which is the challenge of Christian Mission today.

\section{Pastoral Challenges}

New Evangelisation is an invitation to personalise our belief. I believe, not because my parents believed but I have personally chosen to believe. As the disciples told Thomas, "We have seen the Lord" (Jn 20,25). Or like the Samaritans, "We have heard for ourselves" (Jn 4,41). The call for it was already addressed to the whole Church some years ago when Pope John Paul II wrote his encyclical Redemptoris Missio (1990) and said: "There is a situation, particularly in countries with ancient Christian roots, and occasionally in the younger Churches as well, where entire groups of the baptised have lost a living sense of the faith, or even no longer consider themselves members of the Church, and live a life far removed from Christ and His Gospel" (RM 33). The call for a New Evangelisation is relevant not only in the West, but also in Asia on account of the pastoral challenges we have to face today.

a) First among them is the spread of secularism. It seems that a climate which is becoming more and more secular has affected the Christian Churches in India as in the other countries of Asia, more than people of other religious traditions (i.e. Hindu, Muslims and Sikhs). Perhaps it is because Christians are more focused on the material world. The social structures of the past that supported them in their faith, as well as their family life, are now losing their impact. Consequently, many of them do not feel called to something 
beyond themselves. Such an attitude is noticed especially among professionals and people who have had access to higher education.

b) Another pastoral challenge we have to face today is the privatisation of morality. For example, sexual matters like birth control and abortion as well as other issues related to social justice are now seen as private concerns. Many believers do not see the need of following the social teachings of the Church on these matters. Teaching Office of the church to oblige conscience is questioned by many and even met with indifference. As a result, we constantly witness problems of all kinds in the family and the spread of violence in the home as well as in society.

c) The religious climate is such that a growing number of Catholics are leaving the Church to join Protestant sects, as they fail to experience community in the Church and are not put sufficiently into contact with the Word of God. The youth feel disgusted with the routine and the ritualistic worship they attend. This is somehow a tragic situation, because it acts as a counter-witness in the world today and more and more young people allow themselves to be led astray.

d) Moreover, the religious ignorance or the "religious illiteracy" of many Catholics, especially with regard to the Word of God and the teachings of the Church, has become an important concern of pastoral agents in the Church, especially if the Christian faith is to enlighten the commitment of the faithful for the service of society and the Church. Too many Catholics in India, for example, are totally unprepared to give an account of their faith, even to their own children, while they may be attending all kinds of devotional practices.

Considering the pastoral challenges that the Church faces all over the world, and in order to renew the evangelising activity of the Church, Pope Benedict XVI dedicated the theme "New Evangelisation for the Transmission of the Christian Faith" to the XIII Assembly of the Synod of Bishops in October 2012 and created a Pontifical Council for New Evangelisation. He has put New Evangelisation at the epicentre of the universal mission of the Church. It is for us a chosen opportunity to measure the scope of the changes required in matters of evangelisation and to actualise the proclamation of the Gospel today. 


\section{What is New Evangelisation?}

For many people in the Church, the New Evangelisation is a mystery. However, it has been defined clearly by the Popes John Paul II and Benedict XVI. The content of the Christian message is the same as it has been for 2,000 years. What the Church and the world are in need of is a New Evangelisation, not a new Gospel. That requirement is underlined clearly in the Lineamenta for the 2012 Synod of Bishops:

The new evangelisation is not a matter of redoing something, which has been inadequately done or has not achieved its purpose, as if the new activity were an implicit judgment on the failure of the first evangelisation. Nor is the new evangelisation taking up the first evangelisation again, or simply repeating the past. Instead, it is the courage to forge new paths in responding to the changing circumstances and conditions facing the Church in her call to proclaim and live the Gospel today (Lineamenta 5).

On the other hand, we remember that the call for a "New Evangelisation" was voiced for the first time by John Paul II when he addressed the CELAM Assembly on the 9th of March 1983 and said:

The commemoration of the years of evangelisation of your continent will have its full meaning if it is a commitment by you as bishops, together with your priests and people, a commitment not to re-evangelisation but to a new evangelisation, new in its ardour, its methods, its expression (CELAM, 1983).

\section{New Ardour}

The call for a New Evangelisation of the world is an invitation to rediscover the radical character of the Christian faith, the apostolic zeal of the first Christians and the courage of the Apostles to face any challenge. Hence the importance for the evangelisers today is to let themselves be guided by the Spirit in proclaiming Christ and His message to the people of today (Novo Millennio Ineunte $3 \& 30$ ) and in experiencing a new Pentecost. In order to carry out this ambitious project of New Evangelisation, a deep and personal experience of Christ's love, lived in 
the Church, is necessary. According to John Paul II, "those who have come into genuine contact with Christ cannot keep him for themselves, they must proclaim him" (Novo Millennio Ineunte 40).

Pope Paul VI was the first to denounce "the lack of fervour which is all the more serious because it comes from within. It is manifested in fatigue, disenchantment, compromise, lack of interest and above all lack of joy and hope" (EN 80). A similar observation is made in the Lineamenta:

In fact, the obstacles to the New Evangelisation are precisely a lack of joy and hope among people, caused and spread by various situations in our world today. Oftentimes, this lack of joy and hope is so strong that it affects the very tenor of our Christian communities. This is the reason for renewing the appeal for a new evangelisation, not simply as an added responsibility but as a way to restore joy and life to situations imprisoned in fear (Lineamenta 25).

Hence, the evangelisers today must recall how and where they encountered Christ in their lives and not be satisfied with a routine adherence to the Catholic Church, for

the evangelising activity of the Christian community, first in its own locality, and then elsewhere as part of the Church's universal mission, is the clearest sign of a mature faith. A radical conversion in thinking is required in order to become missionary, and this holds true both for individuals and entire communities. The Lord is always calling us to come out of ourselves and to share with others the goods we possess, starting with the most precious gift of all - our faith (RM 49).

The disciples of Emmaus felt their hearts burning within them when they met the Lord after His Resurrection. Many passages in the Acts give us an idea of the interior fire that burned in the hearts of the Apostles and led them to proclaim the Gospel with zeal. "We cannot stop proclaiming what we have seen and heard" (Acts 4,20), said Peter. Zeal and fervour are the effects of what a real encounter with the Risen Christ can produce in the hearts of evangelisers even today. It is only to the extent that they have a deep experience of Christ and feel urged to share that experience with the help of the Spirit that they are prepared to be true witnesses of the living Lord. 


\section{New Method}

The new method of evangelisation has to do with the Kerygma first and secondly catechesis to deepen the faith experience. Right from the beginning, it is important to make a distinction between the Kerygma and Catechesis, as the first Christian always did. The Kerygma is the initial proclamation of faith in Christ and His good news. Catechesis is the deepening of that faith. That is why we can say that the Kerygma is to Catechesis what birth is to growth. The purpose of the New Evangelisation is precisely to bring about a real balance between these two complementary dimensions of the apostolic mission of the Church.

This new missionary pedagogy is centred first on the authentic character of the message and not on the explanation of doctrines and religious observances. It is based on the humble witnessing of authentic Christians and the personal experience of the Father's love, salvation in Christ and the power of the Spirit. Paul VI insisted very much on this non-negotiable requirement of evangelisation, when he said: "Today, people listen more willingly to witnesses than to teachers, and if they listen to teachers it is because they are witnesses" (EN 80).

\section{New Presentation}

This orientation has to do with language. It is an invitation to proclaim Christ and His Good News in the language of today or in ways that can be understood by the people of today. Jesus went out to meet people in the temple, in the synagogues as well as on the roads and in their houses. He proclaimed His Gospel in simple and direct ways, confirming what He said with messianic signs: "He went round the whole of Galilee teaching in their synagogues, proclaiming the good news of the kingdom and curing all kinds of disease and illness among the people" (Mt 4,23). Thus, following the example of Christ, the New Evangelisation adopts three stages of presentation: the inculturation of the message, the proclamation of the Word of God and the healing of the sick. 


\section{What is NEW in New Evangelisation}

For those in the West, it is certainly a call within a much secularised world where people who were born Christians then grew up into a totally secularised world that offered little faith-formation either in the homes or in schools. Their top priority today is to bring Catholics back to the Church. For a whole variety of reasons, people who were once strongly practicing the faith have ceased to practice the faith or maybe don't practice it with the same strength that once they did. It is stated in the preface of the Lineamenta that "new evangelisation is primarily addressed to those who have drifted from the Church in traditionally Christian countries." So their challenge is to bring them back to Christ and also bring them back to the original relationship with the Church.

While responding to a crisis of a loss of faith or no faith, the Church is being challenged to 'preach the gospel afresh'. For this we need to understand the issues of the world today and resonate with the thirst of the people of a secularised world. Recent studies have shown that people even in a much secularised world still seek God and still seek religion for a better life. So the question that challenges us today is to readdress the question of proclaiming the gospel afresh with an emphasis on 'afresh'.

In the Asian Churches, the issue may be somewhat different. It is not secularisation that is of prime importance but very different cultures. We need to ask whether we are sufficiently attuned to the Asian ethos when we proclaim the gospel. The gospel remains alien to the lives of people when it is packaged within a foreign culture; then the people become aliens in their own land. So the Churches in Asia need to address the call to New Evangelisation in a different perspective.

\section{The Concept of New Evangelisation}

New Evangelisation is not a matter of redoing or taking up the first evangelisation again. "Instead, it is the courage to forge new paths in responding to the changing circumstances and conditions facing the Church in her call to proclaim and live the Gospel" (Lineamenta 5). In the second part of the 20th 
century, the concept of the evangelising mission has evolved considerably. Let me bring out five important characteristics of that evolution:

\section{Praying to the Holy Spirit}

Pope Paul VI wrote in Evangelii Nuntiandi:

This is our desire too, and we exhort all evangelisers, whoever they may be, to pray without ceasing to the Holy Spirit with faith and fervour and to let themselves prudently be guided by Him as the decisive inspirer of their plans, their initiatives and their evangelising activity (EN 80).

So it is indispensable for evangelisers to spend time in prayer and to be instructed on certain fundamental aspects of prayer, because they form the foundation of the Christian life. To spend time before God in silence and contemplation always leads them to proclaim the Word in a powerful way, for a missionary or an apostle as Paul claims is the one who has met the Spirit of the Risen Lord!

\section{No Evangelisation without Witnessing}

If all the disciples of Christ are called to share in the evangelising mission of the Church, they should be aware that they, too, have to be evangelised. This auto-evangelisation concerns all Christians in all the dimensions of their lives: faith, prayer, hope, generosity, etc. Before evangelising others, they have to live what they proclaim. As we read in Evangelii Nuntiandi: "The Church always has need of being evangelised and it begins the evangelisation of others by evangelising itself" (EN 15).

\section{Good News to Proclaim}

Today, pastoral agents cannot take for granted that the people to whom they are sent are already evangelised, even if they have been baptised 
long ago. Christ and His message have to be proclaimed to them anew. This means that we have to shift the focus of our pastoral action from children to adults and foster the missionary vocation of our Christian community. This will lead us to ask ourselves whether we are able to proclaim Christ and His message in the language of today, reflecting the meaning of life and discerning the action of God in the world.

The evangelisers today in Asia have also to learn how to function within a multi-cultural and multi-religious society. They should be able to inspire Christians to live their faith in that context. Such a conviction requires that the new evangelisation be carried out in dialogue with other religious traditions in Asia, while safeguarding our fundamental religious convictions and avoiding a polemical approach to the social issues of today.

\section{The Poor First}

In 1979, the Church of Latin America had expressed itself clearly in the Declaration of Puebla: "In solidarity with the poor, we condemn the extreme poverty that affects numerous sectors of our continent as being anti-evangelical" $(1979,1159)$. We can see in this orientation a fundamental characteristic of the New Evangelisation today. It is essentially a missionary option, an option that can be taken only when one lives in solidarity with the poor, keeping in mind that the poor do not include only people who are deprived of material resources, but also all those who are oppressed in one way or another. In the New Evangelisation, concern for the poor should always remain a constant preoccupation of evangelisers in Asia.

\section{All are concerned}

In the light of Vatican II, evangelisation has ceased to be seen by the Catholic Church as a specialised function performed by experts, i.e. professional missionaries. As the Church is missionary by her very nature (LG 1; AG 2) it becomes an intrinsic dimension of the whole Church's life. Evangelisation is no more perceived merely as one of the pastoral 
activities of the Church, but as an expression of her deepest identity. The key-statement of Pope Paul VI is: "The Church exists in order to evangelise" (EN 14). Hence, a missionary responsibility is entrusted to all the baptised. It is the whole Church which is apostolic. The encyclical Redemptoris Missio distinguishes three missionary activities "missio ad gentes", pastoral activity and new evangelisation, within the church.

\section{What is our Particular Context for New Evangelisation?}

New Evangelisation in Asia has to take into consideration two important factors:

1) Firstly, all the Churches in Asia need to be conscious of being a community of the disciples of Jesus Christ.

2) Secondly, take into serious consideration the social, political, religious, cultural and economic realities of Asia (EA 5).

Reflecting on the changing understanding of the Church down through the ages, Avery Dulles in his book, A Church to Believe In, proposes a modest model of the Church as a "Community of the Disciples of Jesus" moving away from the lofty, triumphalist and exalted traditional models such as the "Body of Christ", "People of God" or "Sacrament of Unity." Pope John Paul II of happy memory suggested this model in his first encyclical Redemptor Hominis (RH), "If then we want to have a true picture of this immense and diversified community ... then, it is a Community of Disciples, each of whom follows Christ" (RH 21). This model is also rooted in the Acts of the Apostles, which describes the early Christian community as a community of disciples (Acts 6,2). And, perhaps, we can add here something that should be dear to all missionaries, namely, the mission command as recorded in Mt 28,19, "Go, therefore, make disciples of all nations!" Proclaiming the Good News, building up the Church is making disciples. Mission, in other words, is making disciples of all nations.

Asia, particularly India, is unique in its religious and cultural diversity. It is the cradle of world's major religions and spiritual traditions 
such as Hinduism, Buddhism, Jainism, Sikhism, etc. India is proud of its spiritual and cultural heritage such as love of silence and contemplation, simplicity, harmony, detachment, non-violence, the spirit of hard work, discipline, frugal living, thirst for learning, and philosophical inquiry (EA 6). Living in a multi-religious and multi-cultural context, we need to discover new ways of being church and proclaiming the Gospel.

Along with it, Churches in Asia have to take into consideration the existent economic and political realities. On the one side, the developed countries look enviously at Asian countries, but on the other side we suffer from poverty, crime, terrorism, prostitution and exploitation of the weaker sections. Religious fundamentalists turn to be hostile towards other religions. It is a true challenge to be an authentic Christian and to undertake the mission of evangelisation in this situation (EA 6).

\section{What are the sectors of New Evangelisation?}

- The first sector of evangelisation is culture. Today culture is characterised by the various elements of the modern fast evolving global world.

- The second sector we need to concentrate is the social sector. In this sector we need to be very much aware of the reality of migration.

- The third sector of focus is the means of social communication. It determines the moral and cultural values of human society.

- Fourth sector is economy. The moral values of justice, equality and respect for human life are to be infused into every sphere of economy.

- Fifth sector is scientific and technological research. They are becoming today's new idols. In a digitalised and globalised world, science can easily be considered a new religion.

- The sixth sector is civic and political life. In the various changing situations of the world Lineamenta proposes endeavours like living together, dialogue and collaboration.

\section{Missio Dei - Divine Sending}


The common Missiological understanding is that God's mission is addressed to the world and everyone is a missionary of God, to fulfil the divine plan. This universal mandate ensures the universality of the Gospel that is proclaimed. Christian existence can be characterised as missionary existence. The inclusiveness of the message is the defining element. This proclamation, a participation in the missio Dei, takes on particular forms in response to specific times, places or needs.

What is the basic purpose behind this divine sending? Mark describes the beginnings of Jesus' mission as a call to "repent and believe in the good news" (Mk 1,15). "By calling the people to repent, Jesus is not asking them to leave Judaism and join the Church, but to turn to God by turning away from Satan and Mammon" (AMALADOSS, 2011, p. 42). But in the course of history the basic purpose of Christian mission got oriented towards the salvation of souls, conversion, planting of the Church and its establishment. It was the zeal for the souls that made many missionaries to leave their country in order to preach the Gospel to the people of the world, especially among the non-Christians. The purpose of evangelisation is not salvation of souls, but the creation of a new earth and to give a new direction for human history (PUTHANANGADY, 1992, p. 3).

The Church's mission in Asia is caught in a dilemma: We are conscious of the mission entrusted by Jesus to his disciples to be his witnesses to the ends of the earth (Acts 1,8). The urgency of this mission in our world has been proposed anew by the Council and was emphasised by the post-Conciliar popes, Paul VI and John Paul II. But both felt that the missionary spirit has lost its vigour. A note of sadness is reflected in the words of John Paul II that "the missionary activity, specifically to the nations appears to be decreasing. This is deplorable because "missionary zeal has always been sign of vitality", just as its lessening is "a sign of the crisis of faith". The fulfilment of this mission remains also today "the primary service the Church can render to every individual and to all humanity in the modern world" (RM 2).

\section{New Horizons of Evangelisation: The Multi-Religious Context}


"Today we face a religious situation which is extremely varied and changing" (EN 32). God has placed us in this world and he has given us a variety. And it is part of the mystery of God that there is variety that can be complementary and that it can make a contribution to the totality. So we have to work with other religions, their insights and we have to recognise the positive value of the different cultures. No single religion, conditioned by history and culture, can make a presentation of the total 'Gospel'.

Martin Buber sees man's existence as dialogical. All peoples are included in God's saving love from the beginning as Paul says, "Is God the God of Jews only? Is he not God of Gentiles also?" (Rom 3,29). The awareness of God's grace comes to the people in many ways, mostly through their own religious traditions. The Second Vatican Council has brought about a new understanding of the religious world of nations and firmly stood for a positive appreciation, cordial concord and unity in diversity. In declaration Nostra Aetate on non-Christian religions (NA) the Council declared that "all share in a common origin and destiny, namely God" (NA 1) and recognised with respect "all that is true and holy in these religions" (NA 2). Lumen Gentium reverses the catch phrase St. Cyprian of Carthage, a bishop of the 3rd century, Extra Ecclesiam nulla salus officially and declared that also people "who through no fault of their own do not know the Gospel of Jesus Christ or his Church can find salvation if in their life and work they follow the light of their conscience" (LG 16). In the Mission Decree, the Council also demands that the Christian message should not alienate people from their culture but that every Christian community should be "endowed with the cultural riches of its nation and deeply rooted in the people" (AG 15).

It is a sign of the potential fresh impetus Christianity gives to the universal spirit of openness leading to vasudhaiva kutumbakam (whole world one family). The Second Vatican Council has rekindled in the minds of Christians the fire of interest in and enthusiasm for a meaningful dialogue with the Great Word Religions. Sharing with each other the insights gained through different responses to the mystery of human existence should be a natural activity of people seeking true community in the multi-religious societies. Dialogue, therefore, is both an expression of faith and a sign of hope, to grow together in truth. 
Indian Theological Association (ITA) in its statement says, "The religions of the world are expressions of the human openness to God. They are signs of God's presence in the world. Every religion is unique and through this uniqueness, religions enrich one another. In their specificity, they manifest different faces of that supreme Mystery which is never exhausted. In their diversity, they enable us to experience the richness of the One more profoundly" (Statement 1989, apud ITA, 2002, p. 32). So it seeks to develop a radically new theology of religions relevant for our times, and to evolve new models and styles of inter-religious fellowships.

The mystery of God is much larger than we can imagine. No doubt, it is symbolised or articulated in the Christian tradition. But the mystery of God is also present in the other religions, traditions and movements of people. So the seeds of the Gospel grow, when we recognise the 'beauty' of the land of Asia. Its beauty lies in the deep spirituality that has emerged from the cries of the poor in their anguish and sorrow. The values of the Gospel, centred on hope, cannot give way to despair. In the religious context of Asia in general and India in particular, the Church is called to work towards a living synthesis of an inter-religious spirituality for a human social order. This horizon brings us to a new task, the task of bringing this world into a kind of new fellowship to go forward, trying to understand what the future holds for us.

The Council's wider vision of God's all-embracing saving love and of the religious traditions all over the world has placed the Church's mission in a wider perspective. For ever, Jesus' message has a transforming impact on human society. Pope Paul VI defined the goal of evangelisation as "bringing the Good News into all strata of humanity and through its influence transforming humanity from within". This impact on human society will come about not through laws only, but through the change of hearts, through "conversion", understood, however, not simply in changing religion.

Among all the Asian countries India has a specially privileged position to undertake the challenge of developing a new theology of religions, as all the major World Religions existed in India side by side for centuries. Inter-religious harmony and fellowship has been always part of the Indian ethos. The Christian community in India is challenged 
today to enter more and more deeply into the praxis of dialogue, common commitment to and action for a better society.

Hence, in the multi-religious context of India, evangelisation has a mutually complementary double process: "Communion with Christ, in which the Church and people of different faiths and ideologies share their experience of their ultimate values, and an exchange of brotherly and sisterly love in a tangible form, as they strive together and cooperate with each other for a common end, i.e. fuller and authentic human life" (KAROKARAN, 1978, p. 263). We need to respect followers of other religions as co-pilgrims. Hence, in our context, "Christian mission is better termed missio inter gentes (mission among the nations) than missio ad gentes" (BURROWS, 2001, p. 27), which is the Catholic understanding of evangelisation today.

The proclamation is realised in the mutual self-gift and consequent mutual enrichment of Dialogue, which the SVD XV General Chapter (2000) renamed as a four-fold Prophetic Dialogue with faith seekers, with people of other faith traditions, with people of other cultures, and with the poor and marginalised. "What is expected of missionaries is to listen, to follow, to give witness to, and proclaim the Word of God, and to denounce without fear all that is opposed to the Gospel and the Kingdom of God" (IDW-2/31). Prophetic dialogue is the deepest and best understanding of one's vocation. Missionaries are called to enter the four-fold prophetic dialogue today (STANISLAUS; D'SOUZA, 2003, p. 17).

This new horizon of mission is actually a liberating experience for the missionaries, who were too much attached to the institutions, in order to increase the members of the Church. It was more of proselytization than evangelisation. What is new is the shift from the institution to the people; it is a people oriented evangelisation, which alone makes sense today. Hence, today we need people oriented missionaries, who can gather communities that take care of every member and every section that were neglected. The rise of the Theology of Women and Dalits (a group of people traditionally regarded in India as untouchable), the struggles of peasants and the working class, the tribal and environmental struggles clearly indicate that there were sections that have been really neglected or truths ignored. So it is a way of recapturing what was marginalised. So the new horizon of mission is a kind of evangelisation from the periphery. 


\section{Meeting the Challenges of the New Horizons of Evangelisation}

One way of seeking a solution to the challenges of the new horizons of evangelisation, especially in our multi-religious context may be to look to the pastoral guidelines suggested by the official document of the Papal Secretariat for Dialogue (renamed Pontifical Council for Inter-religious Dialogue). It is the most important of the post-Conciliar documents on dialogue, not only because its aim was to offer a "pastoral solution to the difficulties which can arise from the duties of evangelisation and dialogue" (Dialogue and Proclamation, 1984, p. 7), but also because it conceived the Church's mission in a wider perspective, defining it to be a single but complex and articulated reality.

First of all, it must be granted that inter-religious dialogue is in line with Vatican II (DP 14-15) and it arises because of the need to accept the presence of God's grace and action of the Holy Spirit in other religions (DP 16-17) and to see the history of God's saving deed beyond the boundaries of a chosen people (DP 18-20). Dialogue can be traced to Jesus and His ministry for God's Reign (DP 21-23) and the Early Fathers (DP 24) and developed by the Magisterium (DP 26-27). The pursuit of Dialogue is to be seen on theological foundations too (DP 28-29).

Entering into dialogue with other religions does not mean that we need to accept everything in other religions as good (DP 30). Notwithstanding their positive values, religious traditions reflect the limitations of the human spirit (DP 31). Discernment is required (DP 30). The contradictions found therein cannot be overlooked. Where necessary, we must recognise that there is incompatibility between some fundamental elements of the Christian religion and some aspects of other religious traditions (DP 31). Hence, Christians may also have to challenge followers of other religious traditions, while entering into dialogue with them (DP 32). At the same time, Christians too must allow themselves to be questioned. Although the fullness of God's revelation is there in Jesus Christ, the way Christians sometimes understand their religion and practice may be in need of purification (DP 32). 
What, then, is the place of inter-religious dialogue in the evangelising mission of the Church? The traditional position is that the Church is the universal sacrament of salvation (DP 33 \& 35). This is to be understood with reference to God's Reign (DP 34). Moreover, the Church is to be seen as a pilgrim Church (DP 36). It's "transparency, as sacrament of salvation, is blurred" because of the mark of human limitations. Therefore, it "is constantly in need of renewal and reform" (DP 36). The "revelation is about God and the salvation of people shine forth in Christ, who is Himself both the mediator and the sum total of revelation." But the Church "is always advancing towards the plenitude of divine truth" (DP 37). "The foundation of the Church's commitment to dialogue is not merely anthropological, but primarily theological. God, in an age-long dialogue, has offered and continues to offer salvation to humankind" (DP 38). Thus she "is called to collaborate in God's plan with her methods of presence, respect and love towards all persons". Hence, inter-religious dialogue is fundamental to the Church (DP 39) and an integral element of the Church's evangelising mission (DP 38).

Inter-religious dialogue does not merely aim at mutual understanding and friendly relations. It reaches a much deeper level, that of the Spirit, where exchange and sharing consist in a mutual witness to one's beliefs and a common exploration of one's respective religious convictions. So, Christians and others are invited to deepen their religious commitment to respond with increasing sincerity to God's personal call and gracious self-gift (DP 40). Conversion of all the partners of dialogue to God is indeed the real purpose of dialogue. Granted that dialogue really aims at "a deeper conversion of all towards God" (DP 41), inter-religious dialogue possesses its own validity.

Now, as regards the relationship between inter-religious dialogue and proclamation "both are legitimate and necessary". On the part of the Christian, "true inter-religious dialogue supposes the desire to make Jesus Christ better known, recognised and loved." And his act of "proclaiming Jesus Christ is to be carried out in the Gospel spirit of dialogue". The two activities remain distinct. They are intimately related, but not interchangeable (DP 77). 
In actual fact, the way of fulfilling the Church's mission depends upon the particular circumstances of each Local Church, of each Christian. It always implies certain sensitivity to the social, cultural, religious and political aspects of the situation, as also attentiveness to the "signs of the times" (DP 78). As the Church comes into contact with people of other religious traditions... and in relation to the religions, in dialogue she can be seen to have a prophetic role. In bearing witness to Gospel values, she raises questions for these religions" (DP 79).

The Church encourages and fosters inter-religious dialogue, not only between itself and other religious traditions, but even among these religious traditions themselves. This is one way in which she fulfils her role as "sacrament, that is, a sign and instrument of communion with God and unity among all people" (LG 1). She is invited by the Spirit to encourage all religious institutions and movements to meet, to enter into collaboration, and to purify themselves in order to promote truth and life, holiness, justice, love and peace, dimensions of that Kingdom which, at the end of time, Christ will hand over to His Father as is spoken of in 1 Cor 15,24. "Thus, inter-religious dialogue is truly part of the dialogue of salvation initiated by God" (DP 80).

As regards proclamation, Pope John Paul II reminded us of the duty to proclaim, "Proclamation is the permanent priority of mission. The Church cannot elude Christ's explicit mandate, nor deprive men and women of the 'Good News' about their being loved and saved by God” (RM 44). Also,

Although the Church gladly acknowledges whatever is true and holy in the religious traditions of Buddhism, Hinduism and Islam as a reflection of that truth which enlightens all people, this does not lessen her duty and resolve to proclaim without fail Jesus Christ who is "the way, and the truth and the life" (RM 55).

Insofar as the Church and Christians have a deep love for Lord Jesus, the desire to share Him with others is motivated, not merely by obedience to the Lord's command, but by this love itself. It should not be surprising, but quite normal, that the followers of other religions should also desire sincerely to share their faith. All dialogue implies reciprocity and aims at banishing fear and aggressiveness (DP 83). Christians must also be aware 
of the influence of the Holy Spirit and be prepared to follow wherever in God's providence and design the Spirit is leading them. It is the Spirit who is guiding the evangelising mission of the Church. It belongs to the Spirit to inspire both the Church's proclamation and the obedience of faith. It is for us to be attentive to the promptings of the Spirit. Whether proclamation is possible or not, the Church pursues her mission in full respect for freedom, through inter-religious dialogue, witnessing to and sharing Gospel values. In this way, the partners in dialogue proceed in response to the divine call of which they are conscious. All, both Christians and the followers of other religious traditions, are invited by God himself to enter into the mystery of His patience, as human beings seek His light and truth. Only God knows the times and stages of the fulfilment of the long human quest (DP 84).

\section{New Way of Being Missionary in Asia}

On $24^{\text {th }}$ November 2013, Pope Francis wrote an encyclical entitled, Evangelii Gaudium ('Joy of the Gospel'), in which he reminds us, that the life of every missionary acquires meaning in the encounter with Jesus Christ and in the joy of sharing this experience of love with others. And declaring the 'Year of Consecrated Life' the Holy Father reminded all evangelisers that "The important thing is, not to walk alone, but to rely on each other as brothers and sisters in a wise and realistic pastoral discernment" (EG 33). The new way of being missionaries today, according to him, is the conviction that: "It is not by proselytizing that the Church grows, but by attraction" (EG 15). The pope exhorts missionaries to embark upon a new chapter of evangelization marked by joy and points out new paths for the Church's journey in the years to come (EG 1). He writes this encyclical as a map and a guideline for the mission in the future and to recover also the prophetic vision of mission.

"In this globalized world, we have fallen into globalised indifference. We have become used to the suffering of others, it's none of our business," says Pope Francis. So we have to move from structures that make one agents who execute orders, to those that encourage missionaries to grow in responsibility and creativity. Our relevance must be seen in the thrust of our missionary life and in the dynamism of our spiritual life. It should 
be a self-giving rooted in Jesus, who was a 'man for others'. As Mother Teresa says, "We are not social workers but contemplatives right in the heart of the world." Our hope comes from placing Jesus at the centre of our lives and by becoming signs of God's love for humanity.

\section{Church-centred Mission to Mission-centred Church}

The significant shift that came with regard to mission was from the 'mission of the Church' to the 'mission of God - Missio Dei'. The primary motive of mission is the love of God towards all creation. It made clear that mission has its origins not in the official Church or in special groups within the Church. It has its origin in God. God is a missionary God who crosses frontiers towards the world. Missio Dei implied a shift from a Churchcentred mission to a mission-centred Church. "The mission of the Church and our mission are only at the service of God's mission" (AG 2). There were different interpretations of how the Church stood in relationship to the other movements for humanisation but there was general agreement that Missio Dei was about the renewal of the world, not just renewal of the Church.

Church has a significant role to play in God's continuing mission of humanising humanity and mending the whole of creation. Christ continues to be faithful to the new covenant he made with the Church, which in a mysterious way, is his body. Jesus' prayer that all his disciples may be one, just as he and his Father are one (Jn 17,21) is over-quoted without expounding its implications for today's ever-dividing and fragmented world. The sign of unity and reconciliation among all Christians in single fellowship is the challenge for an effective witnessing in Asia. "The power of evangelisation will find itself considerably diminished if those who proclaim the Gospel are divided among themselves in all sorts of ways," says Paul VI and asks, "Is this not perhaps one of the great sicknesses of evangelisation today?" (EN 77)

Paul says that the whole world is created in him and the people have experienced the divine in various ways and expressed it in various ways and symbols (Col 1). We are sent to discover God who has been there all through the ages, what He has done there, whom He has guided, and 
also to discover the saints God has fashioned. Hence the two areas of concern for the Asian missionaries are:

1) Caring for the needy and the poor, building up solidarity, giving dignity and hope, and making all brothers and sisters, so that we can all together say the Our Father, and

2) Find out what God has been doing throughout the ages and history, and to discover all those who have carried this tradition.

\section{Mission as Reconciliation}

In the plurality of the world today there are different models of mission: when mission is dialogue in our context, it is inculturation in Africa and liberation in Latin America. An important new comer in the world-scene of evangelisation is 'mission as reconciliation'. This felt need is caused by a general sense of brokenness in human society today exasperated by globalisation, and fragmentation that creates it. This sense of division, woundedness, trauma, and dislocation is caused by the upsurge of ethnic conflicts and wars justified by religious fanatics. In this situation of hopelessness people all over not only long for healing but also desire to recreate the whole. In those moments of brokenness, dividedness and alienation people can have an experience of God, and there, I think, we articulate the Good News, trying to help people experience what has happened to them.

Reconciliation as paradigm for Christian mission is expected to address issues of how people of different communities can live together and building bridges towards the society of love, justice and harmony. Christians need to prove that they are followers of Jesus by striving for unity amid diversity as Jesus did (John 17). Reconciliation is seen as an inspiring creative paradigm for mission in the present time. Christian mission is based on the Triune God's plan of salvation where reconciliation is considered as a goal of mission. This may be based on the prevailing situations in many countries having Truth and Reconciliation Commissions formed after civil wars and oppressions, especially after 1990s. Robert Schreiter emphasised that reconciliation is primarily and 
foremost the work of God. He understands reconciliation starting with God as initiator and completing it within us through Jesus.

The Church today needs to recognise that reconciliation must take place not only at a personal and socio-cultural levels but today's situation demands a third level of reconciliation, which might be called political. Personal level could be extended to reconciliation between all victims and their oppressors. Socio-cultural reconciliation between members of oppressed cultural groups like the Dalits in India and those who have oppressed and marginalised them for centuries. In the context of the present day wars justified by terrorist threats, it calls for a political reconciliation between the so-called Christian allied forces and Islamic world. "Reconciliation, insists Robert Schreiter, involves much more of a spirituality than a strategy...In a world that is torn apart by so many conflicts of religion, politics, and human tragedy, the church needs to recognise that Jesus' ministry of reconciliation and peace has been entrusted to us (2 Cor 5:18-19)" (BEVANS, 2003, p. 53).

\section{New Way of Being Church in Asia}

It is beyond doubt that we stand at the definite end of a specific era of the mission in India. Asian theologians are proposing, "A new Missiological paradigm, missio inter gentes for meeting the challenges of the task of carrying out the Christian mission in the diverse and pluralistic Asian Sitzen-im-Leben" (JONATHAN, 2004, p. 672). It is based on the conviction that all are called to transcend their present state in growing towards a fulfilment, which will be the work of the Spirit of God. Hence, church in Asia has to become:

- A sacrament of God's love (Jn 3,34-35). Pope John Paul II says that the Church has but one purpose, "to serve people by revealing to them the love of God made manifest in Jesus Christ" (RM 2). In this context the definition of David J. Bosch on Mission as "the Good News of God's love, incarnated in the witness of a community, for 
the sake of the world" (1991, p. 519), summarises well the new way of being church in Asia.

- A contrast community - Mission in our context is Theocentric (giving glory to God by building up God's Kingdom) and the way to this mission is not so much individual proclamation as community witness. Unless the Church lives as Church, that is, as the symbol and servant of the Kingdom it cannot engage in authentic mission in Asia.

- Open to other religions - discover truth and goodness in others and mutual enrichment through dialogue, adopting the two principles of dialogue - commitment and openness. Following the leadership of the Pope in Assisi in October 1986, the Church can be an instrument of peace. Commentators said that the Pope could not have done this if he did not believe that the members of other religions could pray - i.e. be in touch with God - and that their prayers would be heard. John Paul II also declared that every authentic prayer is from the Holy Spirit, "The Spirit manifests himself in a special way in the Church and in her members. Nevertheless, his presence and activity are universal, limited neither by space nor time (RM 28).

\section{Conclusion}

Evangelisation has twofold basis: "first, the missionary commissioning of the Risen Lord for the participation in the mission of the Most Holy Trinity and second, the impelling force of the joy of Christ experience (Jn 1:39-45; 4:29-30, 40-42; 1 Jn 1:1-4)" (NAMITA, 2000 , p. 204). Down through the centuries there was an over emphasis on the first centrifugal model of mission. It is time, perhaps, that we call a moratorium on an exported idea of mission or a mission necessitated by a western understanding of the Church in the context of Asia. As the very word 'mission' is loaded with suspicion and evokes hatred in 'HinduIndia', it is time that we seize not only using the word but throw away the whole baggage of activity conceptualised in a foreign context and take up seriously the second model, the centripetal model of mission. It is well 
established by the missionary dynamics of the Fourth Gospel and the mission model of Peter in the Acts of the Apostles.

Perhaps it is not an overstatement to assert that 'Spirit consciousness' is uniquely necessary for all evangelisers, particularly in the Asian context. Only the Spirit can foster the awareness and sensitivity needed to approach the diversity of Asian peoples, cultures, religions and the dehumanising situation of its people in poverty and underdevelopment, requiring deep social transformation. All this is possible because the source of its inspiration is "the love of God that has been poured out in our hearts through the Holy Spirit who has been given to us" (Rom 5,5).

\section{References}

AMALADOSS, M. Evangelisation as Dialogue. Indian Theological Studies, n. 1, Mar. 2011. BEVANS, B. S. Unravelling a "Complex Reality: Six Elements of Mission". International Bulletin of Missionary Research, v. 27, n. 2, 2003.

BUBER, M. I and thou. Burlington: Kaufmann Ed., 1970.

BURROWS, W. R. A Response to Michael Amaladoss. Proceedings of the Catholic Theological Society of America, v. 56, 2001.

BOSCH, D. J. Transforming Mission. New York: Orbis, 1991.

INDIAN THEOLOGICAL ASSOCIATION [ITA]. Theologizing in Context: Statements of the Indian Theological Association Statements from the year 1980 to 2001. Bangalore: Dharmaram Publications, 2002. Edition organized by Jacob Parappally.

JOÃO PAULO II. Redeptoris missio. São Paulo: Paulinas, 1990.

JOHN PAUL II. Discourse to the XIX Assembly of C.E.L.AM. (Port au Prince, 9 March 1983), 3: AAS 75, 1983.

KAROKARAN, A. Evangelisation and Diakonia \& The Person of Jesus Christ...of Missionary Proclamation. IMR 16, p. 82-83, 1, 1978. 
THOMAS, J.

NAMITA. A New Paradigm for Evangelisation in the Third Millennium. Bangalore: St. Peter's Pontifical Institute Publications, 2000.

PUTHANANGADY, P. What does Evangelisation mean in the Indian Context? Kristu Jyoti, v. 8, Mar. 1992.

STANISLAUS, L.; D’SOUZA, A. (Eds.). Prophetic Dialogue: Challenges and Prospects in India. Pune: Ishvani Kendra/Delhi: ISPCK, 2003.

TAN, J. Y. From 'Missio ad gentes' to 'Missio inter Gentes'. I.: Shaping a New Paradigm for Doing Christian Mission in Asia. Vidyajyoti Journal of Theological Reflection, v. 68, n. 9, p. 670-686, Sep. 2004.

Received: 08/30/2018

Recebido: 30/08/2018

Approved: 10/25/2018 Aprovado: 25/10/2018 